\title{
Harmony of Ecological Development in the Conditions of the Circular Economy Formation
}

\author{
Olena Kryvda ${ }^{1}$, Svitlana Tulchynska ${ }^{1, *}$, Serhii Smerichevskyi ${ }^{2}$, Nataliia Lagodiienko ${ }^{3}$, \\ Maksym Marych ${ }^{4}$, Aysel Naghiyeva ${ }^{2}$ \\ ${ }^{1}$ Department of Economics and Entrepreneurship, National Technical University of Ukraine "Igor Sikorsky Kyiv Polytechnic Institute", \\ Kyiv, Ukraine \\ ${ }^{2}$ Department of Marketing, National Aviation University, Kyiv, Ukraine \\ ${ }^{3}$ Department of Accounting and Taxation, Mykolayiv National Agrarian University, Mykolayiv, Ukraine \\ ${ }^{4}$ Department of Finance and Credit, Yuriy Fedkovych Chernivtsi National University, Chernivtsi, Ukraine
}

Received November 8, 2021; Revised December 8, 2021; Accepted January 16, 2022

\section{Cite This Paper in the following Citation Styles}

(a): [1] Olena Kryvda, Svitlana Tulchynska, Serhii Smerichevskyi, Nataliia Lagodiienko, Maksym Marych, Aysel Naghiyeva , "Harmony of Ecological Development in the Conditions of the Circular Economy Formation," Environment and Ecology Research, Vol. 10, No. 1, pp. 11 - 20, 2022. DOI: 10.13189/eer.2022.100102.

(b): Olena Kryvda, Svitlana Tulchynska, Serhii Smerichevskyi, Nataliia Lagodiienko, Maksym Marych, Aysel Naghiyeva (2022). Harmony of Ecological Development in the Conditions of the Circular Economy Formation. Environment and Ecology Research, 10(1), 11 - 20. DOI: 10.13189/eer.2022.100102.

Copyright $\bigcirc 2022$ by authors, all rights reserved. Authors agree that this article remains permanently open access under the terms of the Creative Commons Attribution License 4.0 International License

\begin{abstract}
The research is devoted to the actual problem of harmony of ecological development in the conditions of the circular economy formation. The aim of the study is to develop methodological principles for determining harmony of the environmental development in the circular economy formation. To achieve this goal, the main principles of the concept of circular economy were identified, a step-by-step methodological approach to assessing harmony of the environmental development was developed and the proposed developments were tested on the example of the regions of Ukraine. Harmony of ecological development of regions in the conditions of the circular economy formation gives a chance to define a certain balance of the condition of environment that further provides development of directions of circular economy for reception of bigger efficiency of economic and ecological processes. In order to determine harmony of ecological development of regions in the conditions of the circular economy formation, it is offered to define the integrated index of ecological development, and on its base to calculate harmony of ecological development. To determine harmony, it is proposed to apply the "golden section" method using a modified formula of the hyperbolic Fibonacci cone. According to the results of the analysis, the regions are grouped depending on the level of the ecological development harmonization. Calculated and presented data on harmony of ecological development in
\end{abstract}

the circular economy formation demonstrate that the highest average value of harmony have: Odessa $\left(H_{\text {avg }}=\right.$ $0.402)$, Lviv $\left(H_{\text {avg }}=0.349\right)$, Khmelnytsky $\left(H_{\text {avg }}=\right.$ $0.347)$, Zhytomyr $\left(H_{\text {avg }}=0.343\right)$, Ivano-Frankivsk $\left(H_{\text {avg }}\right.$ $=0.343)$ regions. The regions with the lowest level of harmony are Dnipropetrovsk ( $H_{\text {avg }}=0.248$ ), Donetsk $\left(H_{\text {avg }}=0.157\right)$, Transcarpathian $\left(H_{\text {avg }}=0.156\right)$, Luhansk $\left(H_{\text {avg }}=0.143\right)$, Kherson $\left(H_{\text {avg }}=0.171\right)$ regions. It is suggested within the study that not necessarily a high value of the integrated index of ecological development guarantees a high value of harmony of ecological development in circular economy, and vice versa.

Keywords Ecological Development, Circular Economy, Harmony, Development, Environment, Resources

\section{Introduction}

Modern global challenges, the ever-increasing needs of humanity, problems of resource depletion and scarcity, environmental pollution and many other challenges have led to the concept of circular economy that has replaced linear economy of the resource use. The formation of the 
circular economy concept gives a new round of the development to many sectors of economy, providing them with new opportunities for the resource use.

Advantages of circular economy are new opportunities to ensure resource and energy savings, waste disposal, reduction of carbon emissions and general improvement of the ecological state, etc. These and other benefits are achieved through the introduction to fundamentally new concepts of production and its maintenance in which the outputs from one production become resources for another.

The adherence to the paradigm of circular economy makes it possible to achieve different vector goals of economic development of territories, which provides conditions for the formation of a healthy nation by improving the ecological situation.

The outlined reasons require an assessment of environmental development, including regions, which in the future will make it possible to assess the results of the circular economy introduction. The authors consider that to analyze ecological development of the regions, it is appropriate to assess not only through integrated indices, but also to use other methodological approaches, such as determining the level of its harmony.

The aim of the study is to develop methodological principles for determining harmony of environmental development in the circular economy formation. To achieve this goal, the main principles of the circular economy concept were identified, a step-by-step methodological approach to assessing harmony of environmental development was developed and the proposed developments were tested on the example of the regions of Ukraine.

Many scientific researches of the leading domestic and foreign scientists are devoted to the problems of sustainable development of territories, including the ecological component.

A researcher from the Czech Republic [1] emphasizes that the current practice of post-marketing environmental monitoring limits the purpose of identifying unforeseen negative effects of maize cultivation on the environment.

The authors of the article [2], justifying the importance of construction projects, pay special attention to the environmental component and emphasize the synthesis of such aspects as social, economic and environmental in the formulation of the "sustainable development" concept.

The aim of the study by Norwegian scientists [3] was to research children's knowledge about the impact of our actions on the environment and the self-proclaimed sense of belonging to nature. The study found that garbage collection, deforestation, and vehicle air pollution are environmental issues that children were most aware of.

According to the Norwegian scientist [4], environmental sustainability has become a key concept in ecosystem management. The authors proved that paleoecological records can give an idea of the factors that affect the ecosystem sustainability.

The researchers [5-7] developed recommendations that focus on strategic areas that need to be considered for the development of an effective and efficient local innovation ecosystem and improvement of the level and quality of innovation in the industry. The authors analyze the concept of sustainable development in the context of mine management, present the basic principles of sustainable mining and propose tools and mechanisms for implementing strategic priorities of sustainability in business practice.

The authors [8] argue that traditional approaches to environmental biomonitoring have limitations on the identification of species and their ability to take into account spatial and temporal changes. Within the study, the current and future use of nucleic acid-based biomonitoring regimes with an emphasis on fish and aquatic invertebrates and their usefulness for water quality, biodiversity and monitoring of individual species are described.

The papers of scientists [9-12] is devoted to the innovative development of economic systems, aiming at intensifying innovations at both micro and macro levels in order to promote the most efficient use of nature and environmental protection for future generations, which is one of the priorities of sustainable economic growth.

The authors [13] argue that forest resources are an important asset for sustainable social and economic development. The result of the scientists' research is of practical importance for sustainable and healthy development of ecological afforestation projects.

Researchers [14] substantiate the place of waste in the environmental safety management system based on the definition of the process of their formation at all stages of the economic activity of enterprise.

The scientific work [15] examines the tools of sociological research, which is used to study the state and prospects of socio-economic and environmental development of the Karelian Arctic region.

The articles of scientists [16-17] are based on the assessment of the impact of innovative factors on sustainable development of regional economic systems. The study allowed determining the most optimal parameters for managing sustainable development of regional economic systems under the influence of innovative factors. The influence of state management of regional development on the inclusive economy formation is determined.

Within the scientific work [18], the term "environmental obligations" is defined. The scientist's proposals are aimed at improving the management of environmental obligations, optimizing their composition and volume, gaining competitive advantages in foreign and domestic markets, as well as attracting additional investment by disclosing information about environmental obligations in the reports of enterprises.

Italian scientists [19] are studying the air quality data collected by a regional network of stationary stations in the most urbanized areas of the Campania region in the Southern Italy. As a result, useful information was 
gathered on the development of air quality management policies that can be adopted after the implementation of sanitary emergencies to ensure sustainable development of the Campania region.

The authors of articles [20-21] argue that taking into account economic, social and environmental orientation of the regional development gives the most effective impact on the territory development. The study will contribute to the development of measures to increase the level of sustainable development of the regions.

The studies [22-23] are devoted to monitoring the ecological state of regional economic systems in the context of sustainable development on the example of the regions of Ukraine, which provides a systematic diagnosis of the ecological state of the regions. This will make it possible to timely inform regional and local authorities about the real state of the environmental component of sustainable development in order to develop environmental projects.

A scientist [24] from the UK analyzes and critically discusses the role of regions in the implementation of renewable energy policy, the relationship between public policy and the introduction of renewable energy sources. This made it possible to take into account regional specifics, which would ensure sustainable development by promoting the introduction of renewable energy sources.

\section{Materials and Methods}

To determine harmony of ecological development of regions in the circular economy formation, it is proposed to determine the integrated index of ecological development, and to calculate on its basis harmony of ecological development.

To calculate the integrated index of ecological development of regions in the conditions of the circular economy formation, evaluation indicators were determined, which include:

- current costs for environmental protection (in actual prices), UAH million (x1);

- capacity of treatment facilities, million $\mathrm{m}^{3}(\mathrm{x} 2)$;

- emissions of pollutants into the atmosphere from stationary sources of pollution, thousand tons (x3);

- discharge of polluted return waters into surface water bodies, million $\mathrm{m} 3(\mathrm{x} 4)$;

- total amount of waste accumulated during operation in waste disposal sites of hazard class IV (at the end of the year), thousand tons (x5);

- waste generation per person (hazard class IV), thousand tons (x6);

- capital investments for environmental protection, in actual prices, UAH million $\left(\mathrm{x}_{7}\right)$.

To calculate the integrated index of ecological development of regions in the circular economy formation, it is proposed to use the correlation analysis, which allows not only to calculate the value of the integrated index, but also to identify and to take into account the impact of indicators on the integrated index. Coefficients of influence make it possible to identify the nature of changes in the integrated index depending on changes in environmental indicators of regions, which is presented as a regression function. Coefficients of influence when calculating the integrated index of ecological development of regions in the conditions of the circular economy formation gives the chance to reveal influence of changes of circular economy on ecological development of regions.

Indicators of ecological development of regions are divided into regressive and progressive depending on their vector of their impact on ecological development. Thus, to the regressive indicators of the ecological state, in this methodological approach we can relate the following ones:

- emissions of pollutants into the atmosphere from stationary sources of pollution $\left(\mathrm{x}_{3}\right)$;

- discharge of polluted return waters into surface water bodies $\left(\mathrm{x}_{4}\right)$;

- total amount of waste accumulated during operation in the places of waste disposal hazard class IV (at the end of the year) $\left(\mathrm{x}_{5}\right)$;

waste generation per person (hazard class IV) $\left(\mathrm{x}_{6}\right)$.

Other indicators are progressive, as they contribute to the improvement of the environmental situation in regions. To standardize the indicators of environmental development of regions in the circular economy formation, we use the following formulas:

$$
\begin{aligned}
A_{i j} & =\frac{x_{i j}-\min \left(x_{i j}\right)}{\max \left(x_{i j}\right)-\min \left(x_{i j}\right)}, \\
A_{i j} & =\frac{\max \left(x_{i j}\right)-x_{i j}}{\max \left(x_{i j}\right)-\min \left(x_{i j}\right)},
\end{aligned}
$$

where $A_{i j}$ - standardized value of the $\mathrm{j}$-th environmental indicator for the $\mathrm{i}$-th year;

$x_{i j}, \max \left(x_{i j}\right), \min \left(x_{i j}\right)$ - respectively non-standardized value of the $\mathrm{j}$-th environmental indicator for the $\mathrm{i}$-th year and its maximum or minimum value.

Progressors and regressors of ecological development of regions in the conditions of the circular economy formation take part in further calculations of already standardized indicators.

Further economic and mathematical modeling of the integrated index is through the construction of a matrix of standardized values of ecological development of regions, namely:

$$
E=\left[\begin{array}{cccc}
A_{11} & A_{12} & \ldots & A_{18} \\
A_{21} & A_{22} & \ldots & A_{28} \\
\ldots & \ldots & \ldots & \ldots \\
A_{j s} & A_{j s} & \ldots & A_{j k}
\end{array}\right],
$$


where $E$ - matrix of standardized indicators of ecological development of regions in the conditions of the circular economy formation for a certain period (eight years, $k=8$ ) (2013-2020);

$A$ - normalized values of statistical indicators of ecological development of regions in the conditions of the circular economy formation.

To determine the degree of influence of specific assessments of environmental development on the integrated index of environmental development of regions in the circular economy formation, the impact factor $(K)$ is determined by the formula:

$$
K=\left[\left(E^{T} \cdot E\right)^{-1} E^{T}\right] \cdot I,
$$

where $E$ - matrix of standardized indicators of ecological development of regions in the conditions of the circular economy formation;

$I$ - integrated index of ecological development of regions in the conditions of the circular economy formation, which is determined by the formula

$$
I=K_{0}+\sum_{j=1}^{m} K_{i} \cdot y_{i},
$$

where $K_{0}$ - became a component of the impact factor;

$K_{i}$ - weight coefficient of the corresponding indicator of ecological development of regions in the conditions of the circular economy formation;

$y_{i}$ - indicators of the assessment of ecological development of regions in the conditions of the circular economy formation.
Determining the integrated index of ecological development of regions in the conditions of the circular economy formation gives the chance to reveal harmony of the environment condition. To determine harmony, you can use the method known since Pythagoras, namely "golden section" method for the application of a modified formula of the hyperbolic Fibonacci cone, namely

$$
H=\frac{\left(\lambda^{2 \cdot(f)}-\lambda^{-2 \cdot(f)}\right)}{\mu},
$$

where $H$ - harmony of ecological development of regions in the conditions of the circular economy formation of the i-th region according to calculations of golden section;

$\lambda^{f l 0}$ - index of harmony of ecological development of the i-th region;

$\lambda$ - constant of calculation of the "golden section" value is established, namely: $\lambda=1,618$;

$\mu$-constant is set, namely: $\mu=2,236$.

Harmony of ecological development of regions in the conditions of the circular economy formation gives the chance to define a certain balance of the environment condition that further provides development of directions of circular economy for reception of bigger efficiency of economic and ecological processes of the development of regions.

Stages of calculations of harmony of ecological development of regions in the conditions of the circular economy formation are given in Fig. 1.

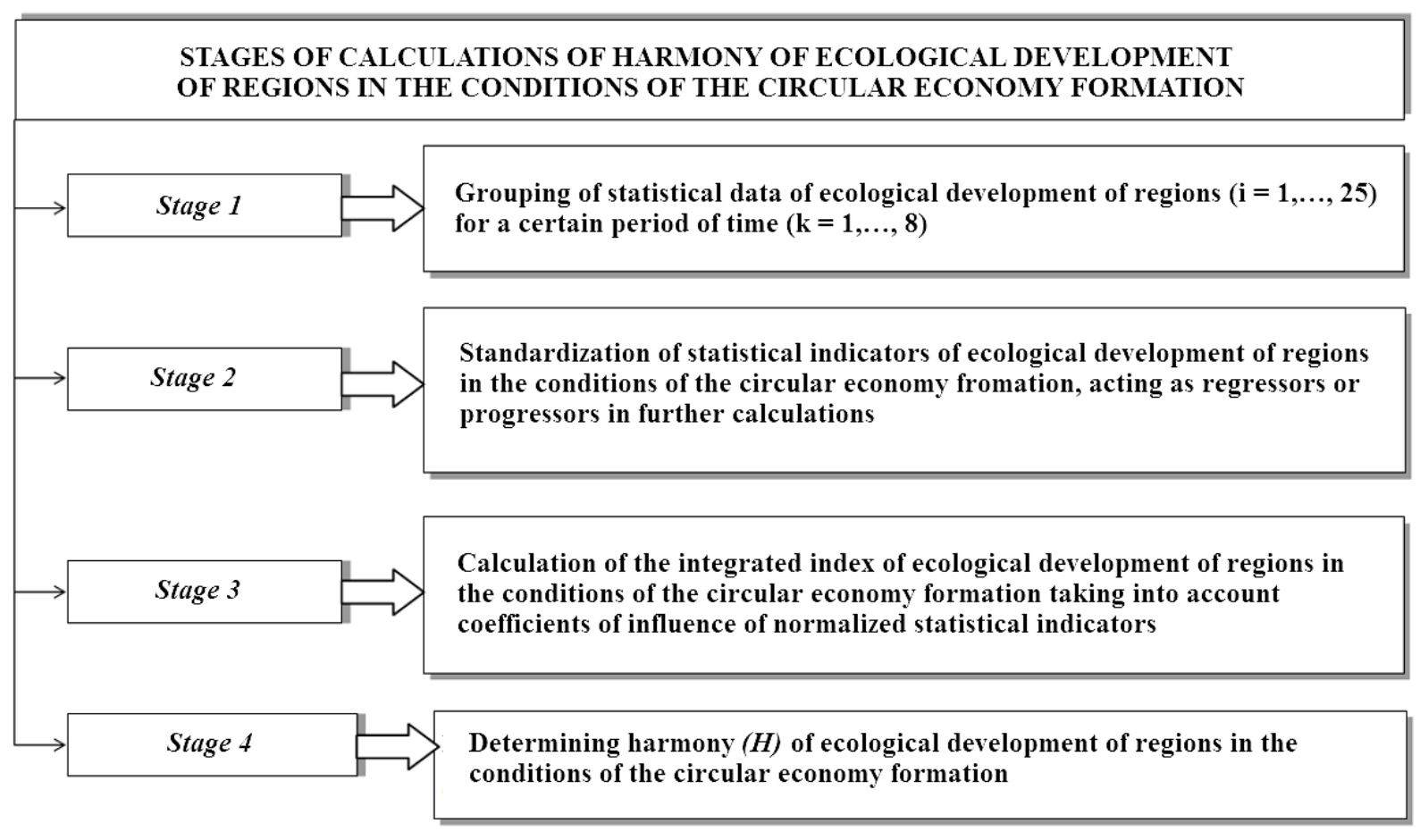

Source: developed and suggested by the authors

Figure 1. Stages of calculations of harmony of ecological development of regions in the conditions of the circular economy formation 
Table 1. The value of integrated indices of ecological development of regions in the circular economy formation in 2013-2020 (I)

\begin{tabular}{|c|c|c|c|c|c|c|c|c|c|}
\hline \multirow[b]{2}{*}{ Regions } & \multicolumn{8}{|c|}{$I$} & \multirow{2}{*}{$\begin{array}{c}I_{\text {avg. }} \\
\begin{array}{c}\text { The average for } \\
\text { 2013-2020 }\end{array} \\
\end{array}$} \\
\hline & 2013 & 2014 & 2015 & 2016 & 2017 & 2018 & 2019 & 2020 & \\
\hline Vinnytsia & 0,231 & 0,231 & 0,214 & 0,211 & 0,204 & 0,218 & 0,241 & 0,271 & 0,228 \\
\hline Volyn & 0,097 & 0,085 & 0,068 & 0,058 & 0,053 & 0,059 & 0,063 & 0,074 & 0,070 \\
\hline Dnipropetrovsk & 0,279 & 0,303 & 0,283 & 0,279 & 0,295 & 0,274 & 0,291 & 0,300 & 0,287 \\
\hline Donetsk & 0,048 & 0,056 & 0,054 & 0,048 & 0,032 & 0,024 & 0,027 & 0,031 & 0,040 \\
\hline Zhytomyr & 0,103 & 0,100 & 0,098 & 0,092 & 0,091 & 0,092 & 0,093 & 0,092 & 0,095 \\
\hline Transcarpathian & 0,065 & 0,071 & 0,070 & 0,056 & 0,047 & 0,059 & 0,068 & 0,070 & 0,063 \\
\hline Zaporozhye & 0,186 & 0,202 & 0,205 & 0,209 & 0,218 & 0,228 & 0,243 & 0,246 & 0,218 \\
\hline Ivano-Frankivsk & 0,330 & 0,274 & 0,235 & 0,243 & 0,274 & 0,294 & 0,299 & 0,306 & 0,282 \\
\hline Kiev & 0,668 & 0,607 & 0,529 & 0,521 & 0,521 & 0,565 & 0,659 & 0,738 & 0,602 \\
\hline Kirovohrad & 0,272 & 0,251 & 0,243 & 0,230 & 0,220 & 0,209 & 0,212 & 0,220 & 0,232 \\
\hline Luhansk & 0,027 & 0,046 & 0,057 & 0,053 & 0,026 & 0,014 & 0,014 & 0,026 & 0,033 \\
\hline Lviv & 0,214 & 0,228 & 0,218 & 0,238 & 0,234 & 0,211 & 0,241 & 0,251 & 0,233 \\
\hline Mykolaiv & 0,092 & 0,090 & 0,083 & 0,081 & 0,087 & 0,095 & 0,098 & 0,092 & 0,090 \\
\hline Odessa & 0,241 & 0,232 & 0,215 & 0,200 & 0,196 & 0,205 & 0,238 & 0,296 & 0,228 \\
\hline Poltava & 0,283 & 0,246 & 0,240 & 0,236 & 0,226 & 0,206 & 0,200 & 0,210 & 0,231 \\
\hline Rivne & 0,082 & 0,092 & 0,103 & 0,111 & 0,094 & 0,093 & 0,082 & 0,075 & 0,092 \\
\hline Sumy & 0,094 & 0,093 & 0,083 & 0,075 & 0,071 & 0,081 & 0,083 & 0,087 & 0,083 \\
\hline Ternopil & 0,080 & 0,073 & 0,064 & 0,053 & 0,047 & 0,060 & 0,074 & 0,075 & 0,065 \\
\hline Kharkiv & 0,205 & 0,254 & 0,276 & 0,248 & 0,205 & 0,180 & 0,193 & 0,229 & 0,289 \\
\hline Kherson & 0,052 & 0,057 & 0,058 & 0,059 & 0,057 & 0,057 & 0,058 & 0,059 & 0,057 \\
\hline Khmelnytsky & 0,282 & 0,219 & 0,195 & 0,181 & 0,165 & 0,192 & 0,231 & 0,246 & 0,214 \\
\hline Cherkasy & 0,081 & 0,075 & 0,078 & 0,085 & 0,079 & 0,084 & 0,085 & 0,065 & 0,079 \\
\hline Chernivtsi & 0,233 & 0,273 & 0,230 & 0,200 & 0,193 & 0,250 & 0,236 & 0,220 & 0,230 \\
\hline Chernihiv & 0,147 & 0,167 & 0,179 & 0,173 & 0,160 & 0,137 & 0,140 & 0,160 & 0,158 \\
\hline Kyiv city & 0,089 & 0,112 & 0,143 & 0,150 & 0,163 & 0,188 & 0,205 & 0,222 & 0,159 \\
\hline $\begin{array}{l}\text { The arithmetic mean value of the } \\
\text { integrated index of ecological } \\
\text { development for all regions }\left(I_{\text {avg. }}\right)\end{array}$ & 0,179 & 0,176 & 0,168 & 0,162 & 0,158 & 0,162 & 0,174 & 0,185 & 0,170 \\
\hline
\end{tabular}

Source: calculated by the authors according to the proposed methodological approach to assessing ecological development of regions in the circular economy formation

\section{Results}

The presented methodological basis for assessing harmony of ecological development of regions in the conditions of the circular economy formation made it possible to test it on the example of the regions of Ukraine using the MathCad - 15 software.

The obtained values of integrated indices of ecological development of regions in the conditions of the circular economy formation are given in Table 1 .

The presented results of calculations for 2013-2020 by regions of Ukraine make it possible to note that the regions have different dynamics of changes in ecological development. Thus, in such regions as Transcarpathian region (from $I=0.186$ in 2013 to $I=0.246$ in 2020) and Kyiv city (from $I=0.089$ to $I=0.222$ ). In Poltava region, on the contrary, there was a negative trend of decreasing the value of the integrated index of ecological development (from $\mathrm{I}=0.283$ to $\mathrm{I}=0.210$ ).

The arithmetic mean value of the integrated index of ecological development for all regions on average for the study period from 2013 to 2020 was $I_{\text {avg }}=0.170$. Such regions as Volyn $\left(I_{\text {avg }}=0.070\right)$, Donetsk $\left(I_{\text {avg }}=0.040\right)$, Zhytomyr $\left(I_{\text {avg }}=0.095\right)$, Transcarpathian $\left(I_{\text {avg }}=0.063\right)$, Luhansk $\left(I_{\text {avg }}=0.033\right)$, Mykolaiv $\left(I_{\text {avg }}=0.090\right)$, Rivne $\left(I_{\text {avg. }}=0,092\right)$, Sumy $\left(I_{\text {avg }}=0,083\right)$, Ternopil $\left(I_{\text {avg }}=\right.$ $0,065)$, Kherson $\left(I_{\text {avg }}=0,057\right)$, Cherkasy $\left(I_{\text {avg }} .=0,079\right)$, Chernivtsi $\left(I_{\text {avg. }}=0,159\right)$ regions average the values of the integrated index for 2013-2020 were lower than the non-arithmetic value of the country as a whole.

The largest average integrated index of ecological development in the conditions of the circular economy 
formation for the studied period was in Kiev region $\left(I_{\text {avg. }}=0,602\right)$, and the lowest value was in Luhansk region $\left(I_{\text {avg }} .=0,033\right)$. Differentiation by the average value of the integrated index of ecological development is more than 18 times. This indicates a very high asymmetry of ecological development between regions and the need to implement conceptual foundations of circular economy to overcome it.

If we consider the dynamics of changes in the arithmetic mean integrated index of ecological development for the period under study, it can be noted that in the period from 2013 to 2017 it had a negative trend. The lowest value of the arithmetic mean integrated index was in 2017, and the highest was in the last studied year, i.e. in 2020. The increase in the value of the integrated index over the past two years illustrates positive trends associated with the implementation of measures on the principles of circular economy.

According to the proposed methodological approach, the main result of the calculations is to determine harmony of ecological development in the circular economy formation. The calculations are presented in Table 2.

Calculated and presented data in Table 2 on harmony of ecological development in the circular economy formation demonstrate that the highest average value of harmony have: Odessa $\left(H_{\text {avg }}=0.402\right)$, Lviv $\left(H_{\text {avg }}=0.349\right)$, Khmelnytsky $\left(H_{\text {avg }}=0.347\right)$, Zhytomyr $\left(H_{\text {avg }}=0.343\right)$, Ivano-Frankivsk $\left(H_{\text {avg }}=0.343\right)$ regions (Fig. 2$)$.

Table 2. The importance of harmony of ecological development of regions in the conditions of the circular economy formation for 2013-2020

\begin{tabular}{|c|c|c|c|c|c|c|c|c|c|}
\hline \multirow[b]{2}{*}{ Regions } & \multicolumn{8}{|c|}{$\boldsymbol{H}_{e c l}$} & \multirow{2}{*}{$\begin{array}{c}H_{\text {ecl.avg }} \\
\text { The average for } \\
\text { 2013-2020 } \\
\end{array}$} \\
\hline & 2013 & 2014 & 2015 & 2016 & 2017 & 2018 & 2019 & 2020 & \\
\hline Vinnytsia & 0,430 & 0,396 & 0,408 & 0,352 & 0,337 & 0,333 & 0,352 & 0,391 & 0,327 \\
\hline Volyn & 0,540 & 0,441 & 0,338 & 0,402 & 0,230 & 0,365 & 0,273 & 0,366 & 0,332 \\
\hline Dnipropetrovsk & 0,206 & 0,307 & 0,352 & 0,330 & 0,328 & 0,267 & 0,260 & 0,219 & 0,248 \\
\hline Donetsk & 0,188 & 0,198 & 0,205 & 0,166 & 0,140 & 0,129 & 0,163 & 0,246 & 0,157 \\
\hline Zhytomyr & 0,465 & 0,392 & 0,449 & 0,428 & 0,370 & 0,334 & 0,355 & 0,345 & 0,343 \\
\hline Transcarpathian & 0,171 & 0,221 & 0,232 & 0,155 & 0,132 & 0,176 & 0,210 & 0,183 & 0,156 \\
\hline Zaporozhye & 0,353 & 0,363 & 0,406 & 0,378 & 0,382 & 0,384 & 0,383 & 0,382 & 0,327 \\
\hline Ivano-Frankivsk & 0,435 & 0,374 & 0,388 & 0,391 & 0,442 & 0,450 & 0,406 & 0,347 & 0,349 \\
\hline Kiev & 0,448 & 0,372 & 0,359 & 0,341 & 0,381 & 0,397 & 0,389 & 0,405 & 0,334 \\
\hline Kirovohrad & 0,417 & 0,452 & 0,385 & 0,389 & 0,338 & 0,344 & 0,226 & 0,310 & 0,326 \\
\hline Luhansk & 0,083 & 0,163 & 0,235 & 0,215 & 0,155 & 0,077 & 0,320 & 0,232 & 0,143 \\
\hline Lviv & 0,482 & 0,484 & 0,492 & 0,389 & 0,332 & 0,310 & 0,322 & 0,337 & 0,349 \\
\hline Mykolaiv & 0,446 & 0,415 & 0,412 & 0,362 & 0,373 & 0,387 & 0,380 & 0,345 & 0,338 \\
\hline Odessa & 0,558 & 0,400 & 0,368 & 0,421 & 0,525 & 0,460 & 0,407 & 0,507 & 0,402 \\
\hline Poltava & 0,452 & 0,369 & 0,385 & 0,382 & 0,404 & 0,384 & 0,331 & 0,275 & 0,328 \\
\hline Rivne & 0,350 & 0,330 & 0,340 & 0,314 & 0,329 & 0,355 & 0,391 & 0,398 & 0,298 \\
\hline Sumy & 0,416 & 0,377 & 0,354 & 0,286 & 0,288 & 0,326 & 0,359 & 0,354 & 0,297 \\
\hline Ternopil & 0,487 & 0,464 & 0,376 & 0,268 & 0,270 & 0,307 & 0,353 & 0,382 & 0,316 \\
\hline Kharkiv & 0,343 & 0,392 & 0,467 & 0,421 & 0,362 & 0,320 & 0,336 & 0,384 & 0,331 \\
\hline Kherson & 0,219 & 0,205 & 0,210 & 0,188 & 0,190 & 0,191 & 0,188 & 0,179 & 0,171 \\
\hline Khmelnytsky & 0,528 & 0,421 & 0,395 & 0,334 & 0,332 & 0,351 & 0,388 & 0,443 & 0,347 \\
\hline Cherkasy & 0,337 & 0,294 & 0,311 & 0,301 & 0,321 & 0,323 & 0,303 & 0,274 & 0,267 \\
\hline Chernivtsi & 0,394 & 0,484 & 0,425 & 0,316 & 0,348 & 0,442 & 0,380 & 0,304 & 0,334 \\
\hline Chernihiv & 0,387 & 0,402 & 0,463 & 0,426 & 0,384 & 0,328 & 0,308 & 0,325 & 0,334 \\
\hline Kyiv city & 0,264 & 0,281 & 0,365 & 0,384 & 0,388 & 0,461 & 0,470 & 0,495 & 0,326 \\
\hline $\begin{array}{l}\text { The arithmetic mean value of harmony of } \\
\text { ecological development in all regions } \\
\left(H_{\text {avg. }}\right)\end{array}$ & 0,376 & 0,360 & 0,365 & 0,333 & 0,323 & 0,328 & 0,330 & 0,337 & 0,299 \\
\hline
\end{tabular}

Source: calculated by the authors. 


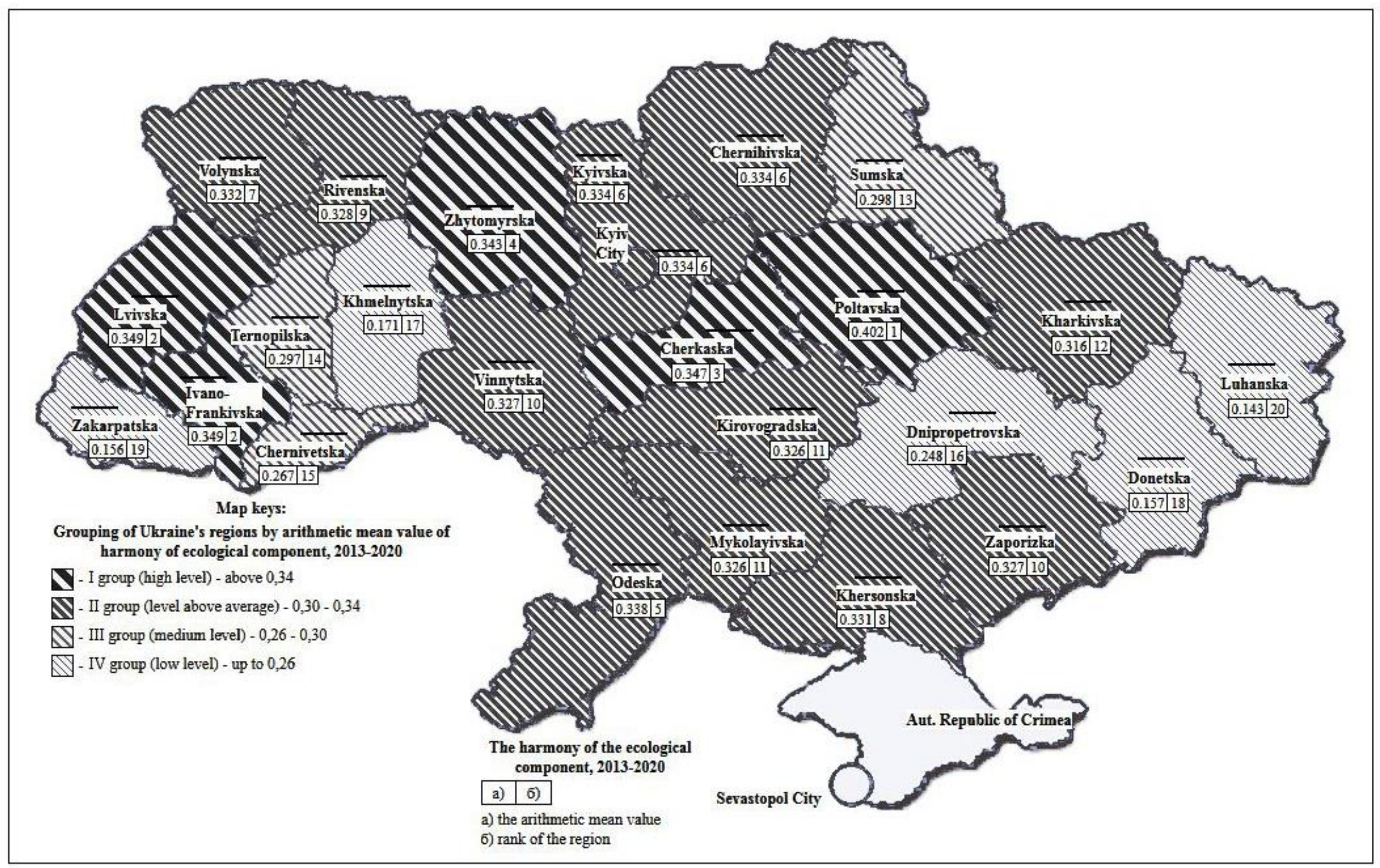

Source: calculated by the authors

Figure 2. Grouping of Ukraine's regions by the arithmetic mean value of harmony of the ecological development in the conditions of the circular economy formation 
The regions with the lowest level of harmony are Dnipropetrovsk $\left(H_{a v g}=0.248\right)$, Donetsk $\left(H_{a v g}=0.157\right)$, Transcarpathian $\left(H_{\text {avg }}=0.156\right)$, Luhansk $\left(H_{\text {avg }}=0.143\right)$, Kherson $\left(H_{\text {avg }}=0.171\right)$ regions. The arithmetic mean value of harmony of ecological development for the period from 2013-2020 in all regions was $H_{\text {avg }}=0.299$.

The highest average value for the studied period of 8 years falls on the Odessa region $\left(H_{a v g}=0.402\right)$, and the lowest in Donetsk ( $\left.H_{\text {avg }}=0.157\right)$. That is, the differentiation is 2.6 times, which is much less than the asymmetry in the values of the integral index.

In Figure 2, the grouping of regions of Ukraine by average values of harmony is presented. Lviv, Poltava, Cherkasy and Zhytomyr regions belong to the first group of regions that have the greatest importance for harmony of ecological development.

The second group of regions that are important for harmony of ecological development in the circular economy formation in the range from 0.330 to 0.340 are Kiev, Volyn, Rivne, Kyiv city, Kharkiv, Kirovohrad, Chernihiv, Vinnytsia, Kherson, Odessa, Mykolaiv, Zaporizhia regions.

Ternopil, Chernivtsi and Sumy regions belong to the third group of regions in which the value of harmony is in the range from 0.260 to 0.330 .

Dnipropetrovsk, Luhansk and Donetsk regions belong to the group of regions that have the least importance of harmony of ecological development, namely to 0.260 .

\section{Discussion}

We support the research of a British scientist [24] who analyzes and critically discusses the role of regions in the implementation of renewable energy policy, as well as analyzes the relationship between public policy and the introduction of renewable energy sources. In our opinion, this will make it possible to take into account regional specifics, which will ensure sustainable development by promoting the introduction of renewable energy sources. In addition, we support a thorough study by scientists [25], which identified the lack of funding for sustainable waste management. The authors' opinion is relevant that companies increase the frequency of waste collection, taking into account the ability of households to pay for these services. We also believe that scientists need to take serious measures against households that illegally dump their waste in undesirable places.

An important contribution to the study of environmental development in the region was made by the authors of the study [26], which examines events that slowly ended the Great Ice Age (GIA) and led to the formation of the Sahara Desert. We consider it an in-depth study of the fact that during 4000-5000 years the grounded and floating ice and continental glaciers melted, and the global sea level rose by 10-15 meters. The author's palebiological, paleohydrological and paleontological observations confirm that the drying up of the Sahara began in earnest about 6,000 years ago, which, in our opinion, is an extremely deep study.

Noteworthy is the study [27], which examined the dynamic relationship between ecological footprint, value added in agriculture, forest areas, non-renewable and renewable energy use and financial development in the BRICS-T countries (Brazil, Russia, India, China, South Africa and Turkey). In our opinion, this study will direct the development of renewable energy; will develop agriculture and the financial sector in order to achieve sustainable development goals.

Our team of authors fully supports the study [28] and considers it a significant contribution to the study of the peculiarities of environmental development. We consider relevant the authors' research on the structure of the socio-ecological system as a tool for identifying key variables in order to identify heterogeneous behavior in different regions. We also support the idea [29] that current trends in sustainable development and the green economy are transforming production processes, leading industries, regional markets, revealing objective contradictions in ensuring the environmental security of individual territories.. The author's developed methodology for assessing environmental safety taking into account the contribution of human capital deserves weight.

We believe that the results of a study by scientists [30] who have shown that there is a nonlinear relationship between the cost of land and the share of ecological land area will be important. It is useful for scientists to study that increasing the resilience of ecosystem protection benefits will slow down the process of land conversion, as well as growing uncertainty of environmental value will accelerate the process of land conversion, which we believe will have a positive impact on environmental development.

However, despite numerous scientific studies in this field, harmony of environmental development in the formation of circular economy is an extremely timely and necessary direction, especially at the international level, which we consider the prospect of further research.

\section{Conclusions}

Thus, it is suggested within the study that not necessarily a high value of the integrated index of ecological development guarantees a high value of harmony of ecological development in circular economy, and vice versa.

The calculations according to the proposed methodological approach to determine harmony of ecological development of regions in the circular economy formation showed a difference in the values of integrated indices of ecological development and the values of harmonization of ecological development. Thus, the 
asymmetry of development according to the integrated index of ecological development between Kiev ( Havg = $0.602)$ and Luhansk (Havg $=0.033)$ regions is 18.24 times. According to the obtained calculations, harmony between Odessa $($ Havg $=0.402)$ and Donetsk $($ Havg $=0.157)$ regions is 2.5 times. These results prove that in the circular economy formation it is important not only to take into account ecological condition of regions, but also harmony of ecological development in general.

The scientific novelty of this study is the development of methodological principles for determining harmony of ecological development in the circular economy formation based on the principles of circular economy and involving the assessment of harmony of ecological development. The assessment of harmony of ecological development is based on the grouping of statistical data of ecological development, their standardization, calculations of integrated indices of ecological development and the determination of harmony using the formula of the hyperbolic Fibonacci cone.

Harmony of ecological development of regions in the conditions of the circular economy formation gives the chance to define a certain balance of the environment condition.

Further developments are required to increase harmonization of ecological development in the context of the circular economy formation and to evaluate their effectiveness.

Another important aspect of further research is to determine harmony of environmental development at the global level, which will contribute to decisions to improve the environmental situation in the world and develop measures to ensure environmental security at the national level.

\section{REFERENCES}

[1] V. Chvátalová. The post-market environmental monitoring of GM maize in the EU has a limited capacity to identify adverse effects, Environmental Science and Policy, Vol.121, 11-17, 2021. https://doi.org/10.1016/j.envsci.2021.03.013.

[2] D. Dzhidzhelava, A. Fedina. The environmental component of construction projects in the aspect of sustainable development, Paper presented at the IOP Conference Series: Materials Science and Engineering, Vol.890, No.1. 2020, 012178. DOI: 10.1088/1757-899X/890/1/012178.

[3] C. Melis, P.-A. Wold, K. Bjørgen, B., Moe. Norwegian kindergarten children's knowledge about the environmental component of sustainable development, Sustainability, Vol.12, No.19, 1-16, 2020. https://doi.org/10.3390/su1219 8037.

[4] A.W.R. Seddon. Special feature: measuring components of ecological resilience in long-term ecological datasets: Palaeoecology and ecological resilience, Biology Letters, Vol.17(1), 2021, rsbl20200881. DOI: 10.1098/rsbl.2020.0 881.
[5] Y. Lazarenko, O. Garafonova, V, Marhasova, N. Tkalenko, S. Grigashkina. Exploring Strategic Directions for the Local Innovation Ecosystem Development in the Mining Industry, E3S Web of Conferences, Vol.174, 02001, 2020.

[6] Y. Lazarenko, O. Garafonova, V. Marhasova, S. Grigashkina, O. Kozureva. Managerial aspects of integrating the sustainable development principles into practices of mining companies, E3S Web of Conferences, Vol.134, 03011, 2019

[7] A. Pinchuk, N. Tkalenko, V. Marhasova. Implementation of circular economy elements in the mining regions, E3S Web of Conferences, Vol.105, 04048, 2019.

[8] H.D. Veilleux, M.D. Misutka, C.N. Glover. Environmental DNA and environmental RNA: Current and prospective applications for biological monitoring, Science of the Total Environment, Vol.782, 146891, 2021. DOI:10.1016/j.scito tenv.2021.146891.

[9] S. Tulchynska, O. Popelo, O. Vovk, B. Dergaliuk, I. Kreidych, T. Tkachenko. The Resource Supply of Innovation and Investment Strategies of the Microeconomic Systems Modernization in the Conditions of Digitalization, WSEAS TRANSACTIONS on ENVIRONMENT and DEVELOPMENT, Vol.17, 819-828, 2021. DOI: $10.37394 / 232015.2021 .17 .77$.

[10] O. Vovk, M. Kravchenko, O. Popelo, S. Tulchynska, M. Derhaliuk. Modeling the Choice of the Innovation and Investment Strategy for the Implementation of Modernization Potential, WSEAS TRANSACTIONS on SYSTEMS and CONTROL, Vol.16, 430-438, 2021.

[11] M. Derhaliuk, O. Popelo, S. Tulchynska, O. Lashuk, S. Khanin. The System Approach to the Organizational and Economic Mechanism of the Innovation Processes Activation of Regional Economic Systems, Estudios de Economia Aplicada, 40(1): Sports Analytics within Sports Economics and Management, 2022. DOI:10.25115/eea.v40i1.5318.

[12] O. Popelo, S. Tulchynska, N. Lagodiienko, A. M. Radin, A Moskalenko. Methodical Approach to Forecasting the Intensification of Innovative Development of Regions Using the Mathcad Program, International Journal of Circuits, Systems and Signal Processing, Vol.15, 1591-1601, 2021. DOI: 10.46300/9106.2021.15.171.

[13] W. Zhang, Z. Wang. The ecological afforestation project benefit evaluation of the regional sustainable development: Example of the Southeast Region of China, Fresenius Environmental Bulletin, Vol. 29(12), 11545-11555, 2020.

[14] V. Anishchenko, V. Marhasova, A. Fedorenko, M. Puzyrov, O. Ivankov. Ensuring environmental safety via waste management, Journal of Security and Sustainability Issues, Vol.8, No.3, 507-519, 2019.

[15] A. Volkov. Methodological approaches to the study of socio-economic constraints on sustainable development of the Karelian Arctic region in modern conditions, E3S Web of Conferences, Vol.203, 05023, 2020.

https://www.e3s-conferences.org/articles/e3sconf/pdf/2020 /63/e3sconf_ebwff2020_05023.pdf.

[16] S. Tulchynska, O. Popelo, O. Garafonova, I. Yaroshenko, I. Semyhulina. Modeling the influence of innovative factors on sustainable development of regions in the context of digitalization, Journal of Management Information and 
Decision Sciences, Vol. 24(S5), 1-8, 2021. DOI: 1528-2635-24-8-367.

[17] A. Revko, M. Butko, O. Popelo. Methodology for Assessing the Inflence of Cultural Infrastructure on Regional Development in Poland and Ukraine, Comparatie Economic Research. Central and Eastern Europe, Vol.23(2), 21-39, 2020

[18] I.V. Zamula. Accounting component of environmental liabilities management according to the principles of sustainable development, Actual Problems of Economics, Vol. 166(4), 261-267, 2015.

[19] D. Toscano, F. Murena. The effect on air quality of lockdown directives to prevent the spread of SARS-CoV-2 pandemic in Campania Region-Italy: Indications for a sustainable development, Sustainability, Vol. 12(14), 5558, 2020. https://www.mdpi.com/2071-1050/12/14/5558.

[20] O. Popelo, S. Tulchynska, Y. Kharchenko, B. Dergaliuk, S. Khanin, T. Tkachenko. Systemic Approach to Assessing Sustainable Development of the Regions, Journal of Environmental Management and Tourism, Vol. XII, No.3, Is.3(51), 742-753, 2021. DOI: 10.14505/jemt.v 12.3(51).13.

[21] S. Shkarlet, N. Ivanova, O. Popelo, M. Dubina, O. Zhuk. Infrastructural and Regional Development: Theoretical Aspects and Practical Issues, Studies of Applied Economics, Vol.38, No.4, 2020.

[22] S. Tulchynska, O. Popelo, V. Marhasova, O. Nusinova, Zh. Zhygalkevych. Monitoring of the Ecological Condition of Regional Economic Systems in the Context of Sustainable Development, Journal of Environmental Management and Tourism, Vol.12, No.5, 1220-1228, 2021. https://doi.org/1 $0.14505 / / j e m t . v 12.5(53) .06$.

[23] A. Abramova, K. Shaposhnykov, A. Zhavoronok, P. Liutikov, I. Skvirskyi, O. Lukashev. Ecosystem of VAT Administration in E-Commerce: Case of the Eastern Europe Countries. Estudios de economía aplicada. 2021. 39(5). http://dx.doi.org/10.25115/eea.v39i5.4909
[24] De Laurentis. Mediating the form and direction of the regional sustainable development: The role of the state in renewable energy deployment in selected regions, European Urban and Regional Studies, Vol. 27(3), 303-317, 2020. https://journals.sagepub.com/doi/abs/10.1177/09697 76420904989 .

[25] S. Yasin. Assessing Households' Willingness to Pay for Improved Solid Waste Management Services in Jigjiga, Ethiopia. Environment and Ecology Research, 9(2), 39-44, 2021. DOI: 10.13189/eer.2021.090201.

[26] K. Hänninen. The Formation of the Sahara Desert: Evidence for the Slow Ending of the Great Ice Age. Environment and Ecology Research, 9(2), 76-91, 2021. DOI: 10.13189/eer.2021.090204.

[27] M. Usman, M.S.A. Makhdum. What abates ecological footprint in BRICS-T region? Exploring the influence of renewable energy, non-renewable energy, agriculture, forest area and financial development. Renewable Energy, 179, 12-28, 2021. DOI: 10.1016/j.renene.2021.07.014.

[28] R. Fernández-González, M.I. Pérez-Pérez, M.D. Garza-Gil. Main issues and key factors for development of turbot aquaculture in Spanish regions: A social-ecological perspective. Aquaculture, 544, 737140, 2021. DOI: 10.1016/j.aquaculture.2021.737140

[29] S. Demidova, M. Balog, T. Chircova, A. Kulachinskaya, S. Zueva, I. Akhmetova, S. Ilyashenko. Development of the methodology and assessment of ecological safety of the EAEU and CIS regions in the context of sustainable development. Economies, 9(3), 100, 2021. DOI: 10.3390/economies9030100.

[30] J. Li, S. Lu, X. Qi, H. Yang. The real option model of the land development and ecological protection-A case study of Three Rivers Source Region. Zhongshan Daxue Xuebao/Acta Scientiarum Natralium Universitatis Sunyatsen, 60(4), 60-75, 2021. DOI: 10.13471/j.cnki.acta.snus.2020.05.28.2020D023. 